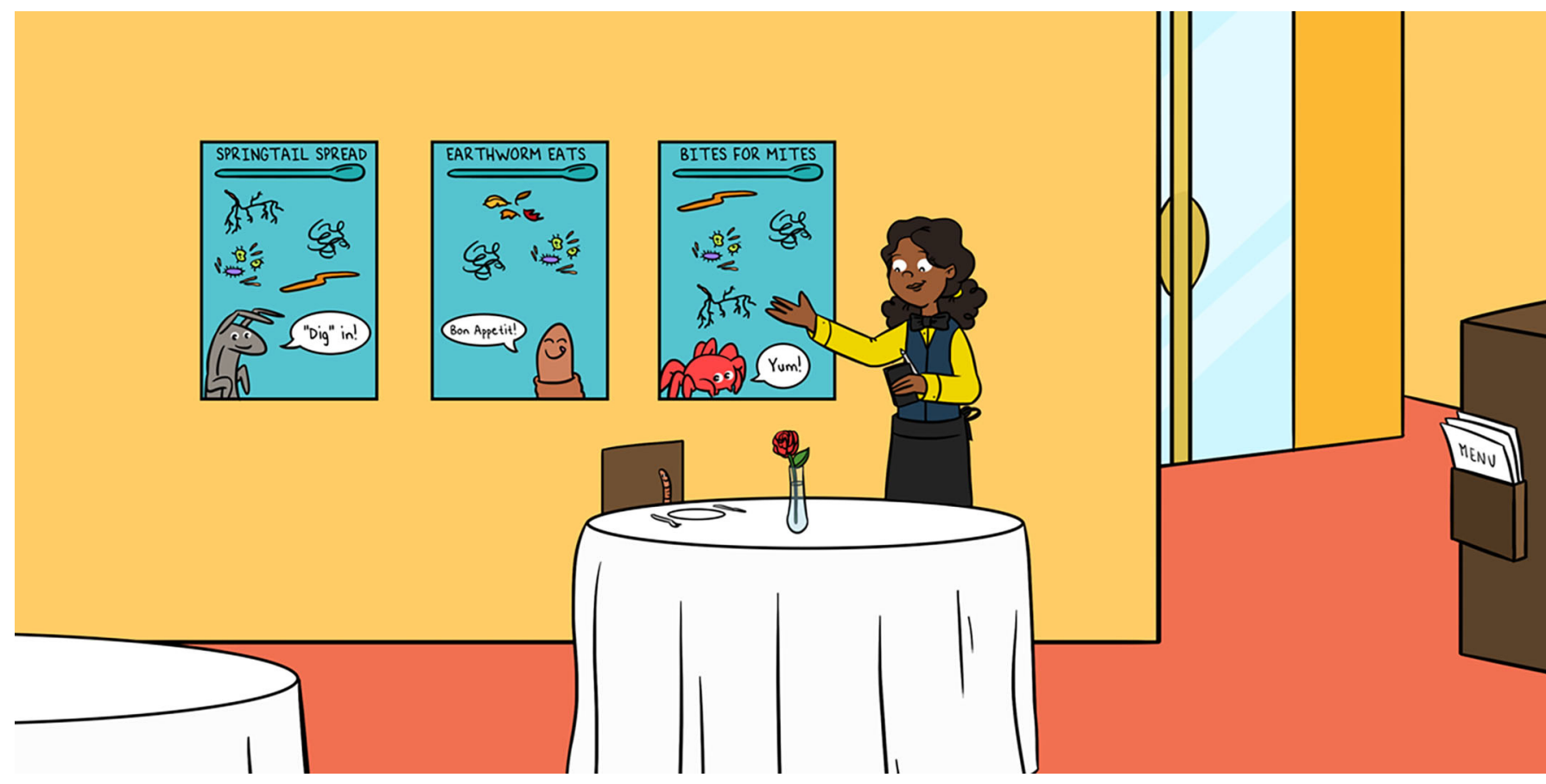

\title{
SOIL ECOLOGISTS AS DETECTIVES DISCOVERING WHO EATS WHOM OR WHAT IN THE SOIL
}

\section{Amandine Erktan $^{1 *}$, Melanie M. Pollierer ${ }^{1}$ and Stefan Scheu ${ }^{1,2}$}

${ }^{1}$ J.F. Blumenbach Institute of Zoology and Anthropology, University of Göttingen, Göttingen, Germany

${ }^{2}$ Centre of Biodiversity and Sustainable Land Use, University of Göttingen, Göttingen, Germany

YOUNG REVIEWERS:

CECÍLIA

AGE: 9

NYNKE

AGE: 12
Did you ever notice that dead leaves never accumulate in forests? For that service, we can thank a cleaning team of tiny recyclers living in the soil. Dead organisms are their food source, and they recycle them by just eating them. Knowing who eats what or whom in soils is essential to understand this recycling machinery. But that is hard to know, because many soil animals are tiny, hidden in the soil, and unable to tell us what they ate! To bypass these difficulties, soil ecologists have developed a special method. They track specific markers of bacteria, fungi, and plants in the fat of animals and hence can identify what they fed on. Some animals consume a large variety of food sources, others are more specific. Remarkably, many organisms have developed amazing strategies to feed in soil, because finding food in such a dark maze is not that easy! 


\section{WHY IS IT IMPORTANT TO UNDERSTAND WHO EATS WHOM OR WHAT IN SOILS?}

Have you ever noticed that we never see huge piles of dead leaves accumulating in the forest? It is also very rare to encounter a dead animal lying on the forest floor. That should encourage us to ask the question, "who is cleaning the forest floor?" In cities, city workers remove all the dead leaves. In the forest, the work is done by a team of tiny recyclers living in the soil. For these small soil animals, dead organisms are a food source and they recycle leaves and other dead things by just eating them. When the soil animals defecate (meaning poop) they release nutrients that can be used by plants to grow. Or, small soil animals are eaten by larger animals, and that allows the bigger animals to grow. This process allows the recycling of nutrients and is essential to help plants grow. It is also very important for humans, as plants provide us with plenty of goods, such as foods like vegetables, cereals, and fruits, and also wood to build furniture and houses. Understanding who consumes what in soil is essential to understand this precious recycling machinery.

\section{WHAT KIND OF FOOD IS IN SOIL ... AND WHAT IS A SOIL FOOD WEB?}

What kind of food is in the soil? If you dig in soil in the forest, you would not find a plate with spaghetti Bolognese! We are not talking about this kind of food, of course! In soil, the basic food sources are dead tissues from plants and other organisms (dead leaves or dead soil organisms of any size), and plant roots (Figure 1A). These basic food sources are mainly consumed by bacteria and fungi, which are called

PRIMARY

CONSUMER

Organisms directly consuming the dead plant material.

\section{SOIL FOOD WEB}

All the links indicating who consume whom or what in soil. primary consumers. Fungi and bacteria themselves are the main food source for larger organisms, such as protists, nematodes, springtails, and mites (about 0.1-2 mm; Figure 1). These organisms again are eaten by larger predators (a few millimeters in size), such as centipedes and spiders (Figure 1B). Earthworms also mainly eat bacteria and fungi, but in a special way, they eat them together with soil (Figure 1B). This is a bit like if you ate the food on your plate together with the plate!

Although some soil animals, such as springtails or nematodes, mainly eat tiny living creatures like bacteria and fungi, they can also eat plant tissue, notably the roots or the nutritious liquid roots release. Altogether, there are many food sources in soil, ranging from plant to animal tissues and from dead to living organisms, and most soil organisms consume several of these food sources. All the links of who consumes what or whom is called a soil food web (Figure 1A). 
Figure 1

Organisms in a typical soil food web. (A) A food web contains basic food sources, like plant roots and dead organisms, as well as primary and secondary consumers and a selection of predators. Arrows indicate who consumes what or whom. Note that primary consumers are a food source for secondary consumers, which themselves are a food source for predators. (B) Here you can see examples of soil primary and secondary consumers as well as predators.

A

B
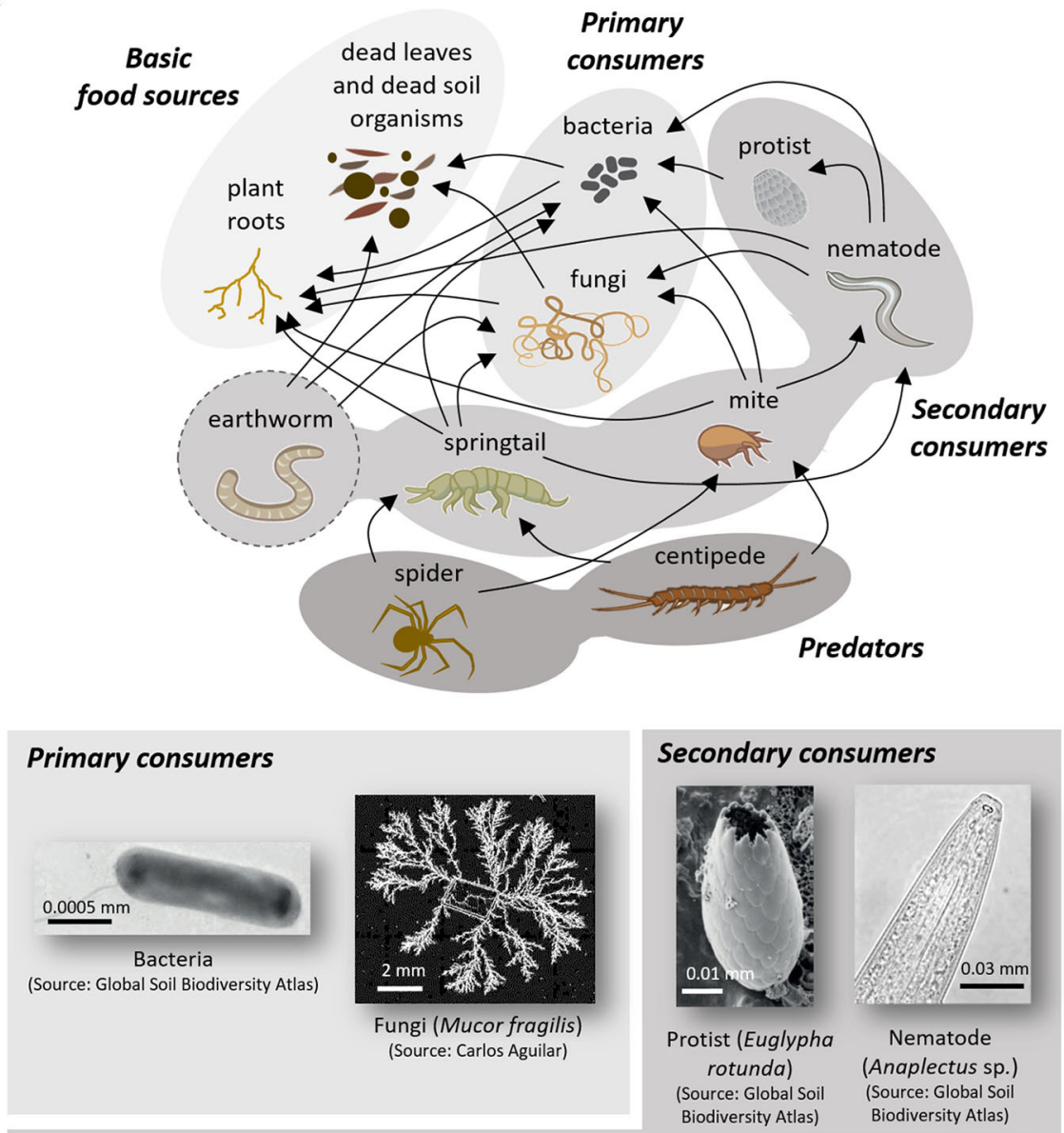

Secondary consumers
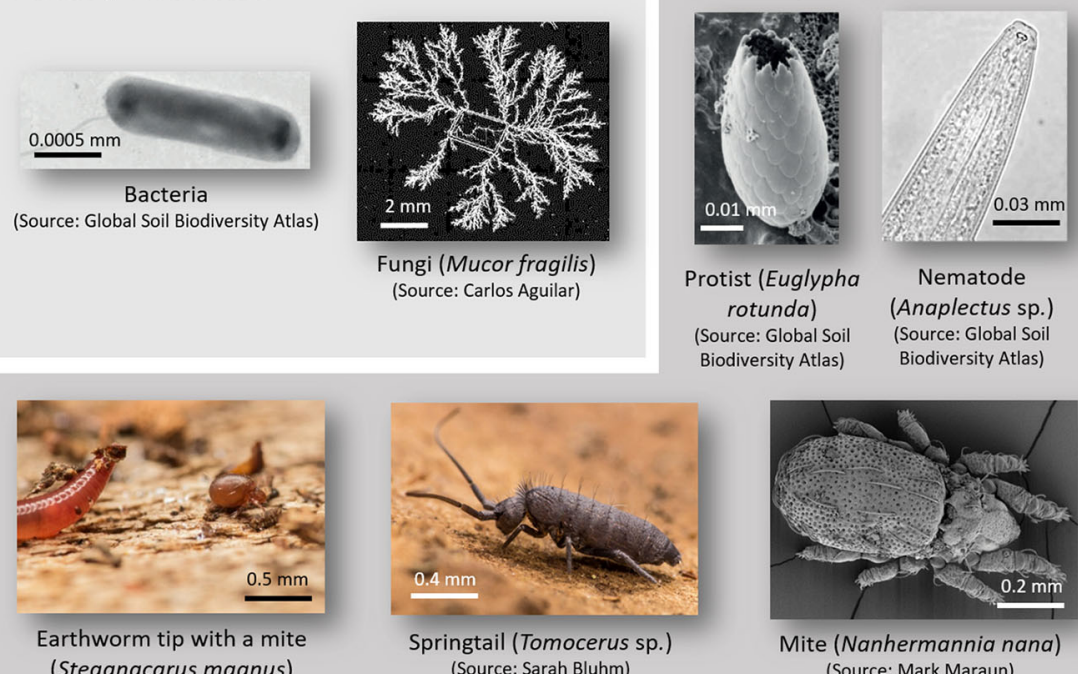

(Steganacarus magnus)

(Source: Sarah Bluhm)
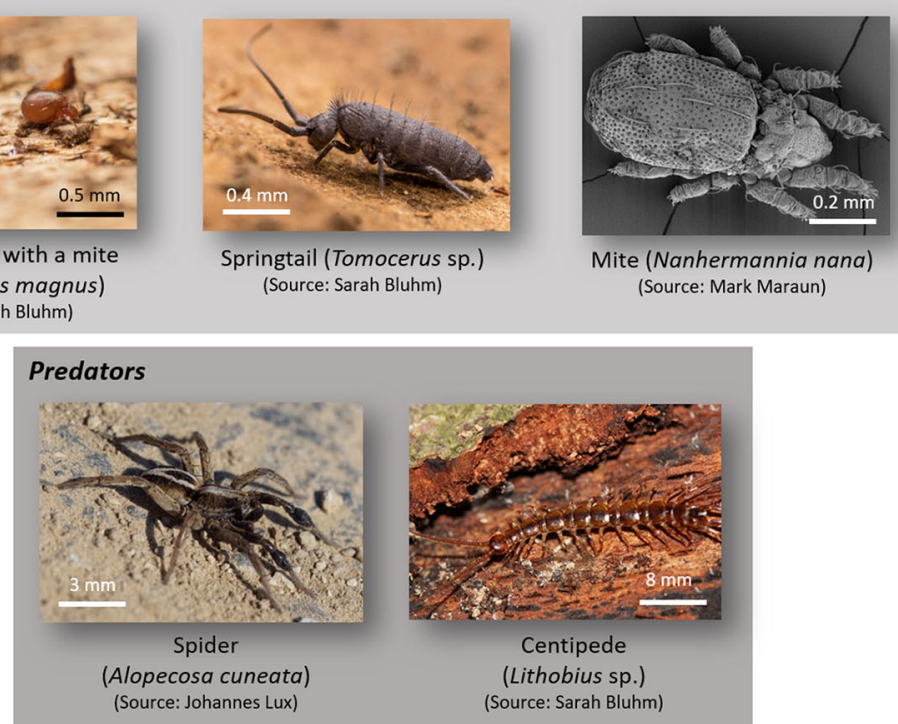

Figure 1

\section{HOW DO WE STUDY SOIL FOOD WEBS?}

Despite all the research that has happened in the last decades, researchers still know little about who consumes what or whom in soil. This lack of knowledge is because soil animals are tiny, hidden 
Figure 2

Determining what soil organisms eat by looking at fatty acid markers. (A) Soil animals have different types of fats in their bodies, depending on the food sources they eat, such as bacteria, fungi, or dead leaves. (B) The fats can be extracted (removed) from these animals in the form of fatty acids. (C) Those fatty acids can then be analyzed using a piece of equipment called a gas chromatograph. The data from the gas chromatograph allows researchers to identify which foods the soil organisms ate.
FATTY ACID

\section{MARKERS}

Molecules of fat which are specific from a food source, namely bacteria or fungi.

\section{FOOD GENERALIST}

Soil organisms consuming many types of food resources.

\section{FOOD SPECIALIST}

Soil organisms consuming specifically one or a few types of food resources only.
A

\section{Soil animals eating various food sources}

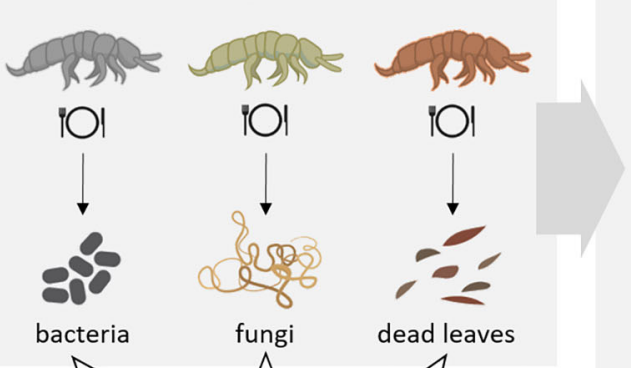

C

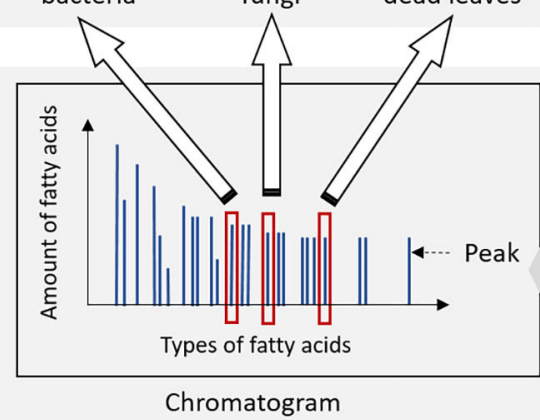

The analysis of the composition of fatty acids reveals which food source was eaten by the soil animals
B

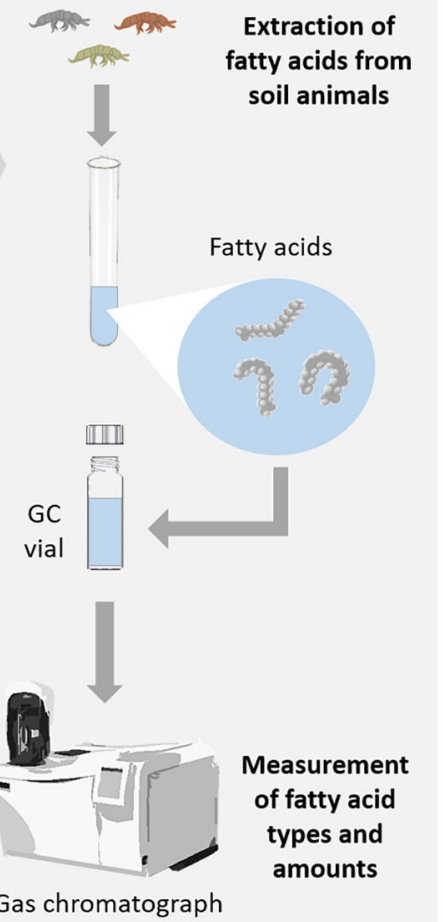

Figure 2

in the soil, and cannot tell us what they ate! To know who consumes what in the soil, researchers must act as detectives. They developed a curious method: they study the fat of soil animals (Figure 2). When you eat something, the food serves as a source of energy, so you can grow and be active. However, you cannot use all the energy at once, so your body must store it for later use. How is energy stored? When we eat more than we need at that moment, the body builds up fat as an energy-storage tissue. The fat will later be "burned" for energy when we need it. For both humans and animals, it is even easier for the body to take up and store the fat that is already in the food, instead of making new fat. Now, the trick is that not all fat is the same! Bacteria, fungi, and plants have different types of fat, and researchers can track these so-called fatty acid markers in the animals that consumed these food sources [1]. So, in the end, we can identify if the fat stored in an animal has come from bacteria, fungi, or plants-and thus know what they ate.

\section{FOOD GENERALISTS VS. FOOD SPECIALISTS}

By studying the fat of soil animals, researchers discovered that many springtails preferably feed on fungi, but can also eat bacteria or plants. Because they can eat different food sources, they are considered food generalists [2]. This means that they are not difficult to satisfy if you invite them for dinner! Some other organisms are food specialists and tend to eat only one thing. For example, some nematodes prefer 
Figure 3

Animals have

developed ways to deal with the difficulty of feeding in the dark soil. (A) Small holes in the soil provide a place for tiny soil organisms (nematodes, protists, and bacteria) to hide from the animals that eat them. (B) To reach its prey, an amoeba (a type of protist) can extend an arm 20 microns long and 1 micron thin to catch bacteria hidden in small soil holes. (C) Springtails are flexible in the food sources they consume, allowing them to have something to eat each day. (D) Earthworms ingest soil along with their food and digest the bacteria and fungi contained in the ingested soil. This also creates a path through the soil maze, making it easier for them to travel through it. Remember 1 micron is 1,000 times smaller than $1 \mathrm{~mm}$.
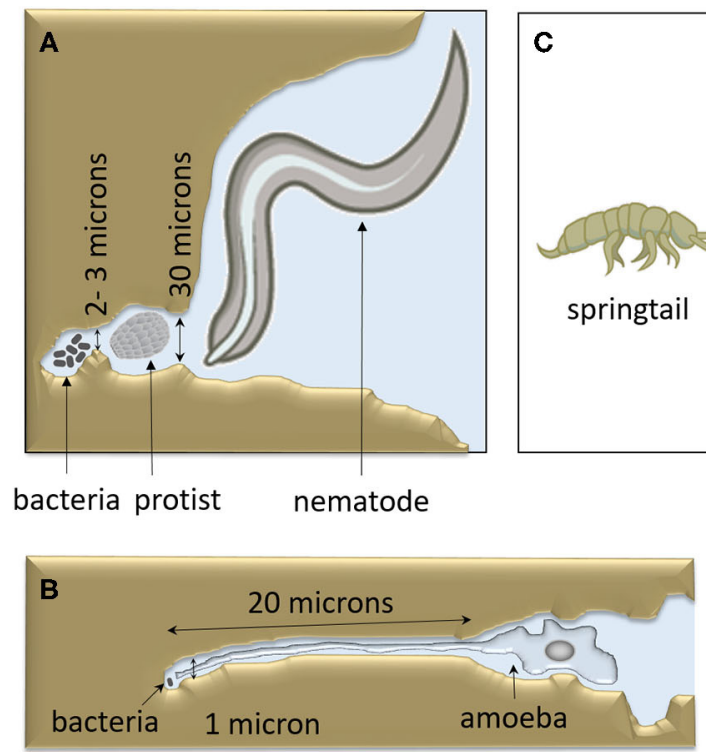
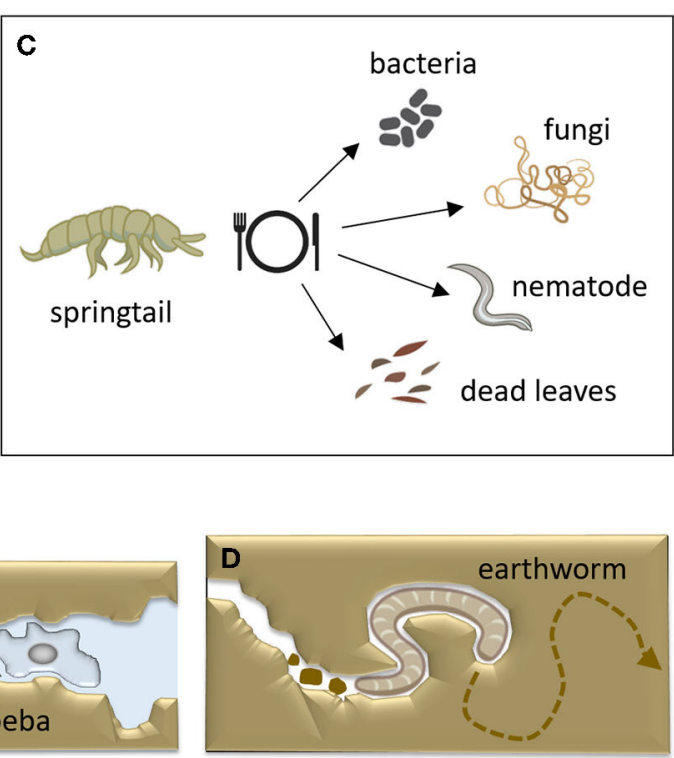

Figure 3

eating bacteria, while others prefer fungi. There are even predatory nematodes that eat other nematodes! Each class of nematode has a different mouth shape, specific for eating a certain type of food.

\section{WHY IS IT SO SPECIAL TO FEED IN THE SOIL?}

Soil is dark. Have you ever tried to eat your dinner in the dark? It is not that easy to find where the food is. Soil animals have the same problem. Eyes do not work in the soil, so many soil animals do not even have them. By contrast, most soil animals have very fine "noses." For example, nematodes, springtails, and earthworms are very efficient at smelling their food. They can detect the location of food and move toward it. Nematodes can "smell" bacteria up to $50 \mathrm{~cm}$ away and reach them in 2 weeks [3]. This is a considerable distance for a nematode, as these little worms are usually only a few hundred microns long (1 micron $=0.001 \mathrm{~mm}$; for comparison, the width of a human hair is 100 microns). This would be like humans being able to smell food from about $70 \mathrm{~km}$ away!

Soil is not only dark, it is also a maze, through which soil organisms cannot freely move. Soil is like a sponge with larger holes and smaller holes. The smaller organisms, such as the bacteria, typically measure 1-2 microns and can "hide" in small holes. For example, we know that protists (Figure 1) cannot reach bacterial prey if the bacteria are located in holes smaller than 2-3 microns [4] (Figure 3A). The same applies to nematodes, which cannot eat bacteria located in holes with openings smaller than 30 microns [4] (Figure 3A). The smaller the holes in soil, the more the bacteria can hide in them and avoid being caught and eaten by predators. But predators have developed strategies to feed despite these problems. For example, amoebae (the 
plural of "amoeba") are protists with soft bodies that can adopt any shape (Figure 3B). Amoebae can extend a very thin and long "arm" into small soil holes to catch hidden bacteria [5]. Springtails have a different strategy: they are simply not very picky about the food sources they consume-they are food generalists. They can eat bacteria and fungi, but also dead leaves and nematodes (Figure 3C). Depending on what is available in the small holes of the soil they are crawling through, they eat one food source or another. This flexibility helps them to have something to eat every day. Earthworms are less affected by the difficulties of accessing food in the soil. These animals directly ingest soil, enabling them to search for and access food easily in the soil maze (Figure 3D). Moreover, they can digest bacteria and fungi, as well as dead plant material that is ingested with the soil. When earthworms poop, the undigested leftovers typically form small bowls of soil.

\section{A NEW LOOK INTO FEEDING IN A DARK MAZE}

Feeding in soil is like finding food in a dark maze. To understand who eats whom in the soil darkness below our feet, soil ecologists have to act as real detectives and using all sorts of complicated techniques, either in the forest or in the laboratory. Now that you know what it is like to feed in soil, you will never look at soil animals in the same way!

\section{ACKNOWLEDGMENTS}

This research has been supported by the European Commission Horizon 2020 research and innovation program, Marie Skłodowska-Curie actions (grant no. 750249). We are thankful to Audrey Marville for drawing the soil animals.

\section{REFERENCES}

1. Ruess, L., and Chamberlain, P. M. 2010. The fat that matters: soil food web analysis using fatty acids and their carbon stable isotope signature. Soil Biol. Biochem. 42:1898-910. doi: 10.1016/j.soilbio.2010.07.020

2. Digel, C., Curtsdotter, A., Riede, J., Klarner, B., and Brose, U. 2014. Unravelling the complex structure of forest soil food webs: higher omnivory and more trophic levels. Oikos 123:1157-72. doi: 10.1111/oik.00865

3. Rasmann, S., Köllner, T. G., Degenhardt, J., Hiltpold, I., Toepfer, S., Kuhlmann, U., et al. 2005. Recruitment of entomopathogenic nematodes by insect-damaged maize roots. Nature 434:732. doi: 10.1038/nature03451

4. Rønn, R., Vestergård, M., and Ekelund, F. 2012. Interactions between bacteria, protozoa and nematodes in soil. Acta Protozool. 51:223-35. doi: 10.4467/ 16890027AP.12.018.0764

5. Foster, R. C., and Dormaar, J. F. 1991. Bacteria-grazing amoebae in situ in the rhizosphere. Biol. Fertil. Soils 11:83-7. doi: 10.1007/BF00336368 
SUBMITTED: 22 March 2020; ACCEPTED: 26 October 2020;

PUBLISHED ONLINE: 19 November 2020.

EDITED BY: Rémy Beugnon, German Centre for Integrative Biodiversity Research (iDiv), Germany

CITATION: Erktan A, Pollierer MM and Scheu S (2020) Soil Ecologists as Detectives Discovering Who Eats Whom or What in the Soil. Front. Young Minds 8:544803. doi: $10.3389 /$ frym.2020.544803

CONFLICT OF INTEREST: The authors declare that the research was conducted in the absence of any commercial or financial relationships that could be construed as a potential conflict of interest.

COPYRIGHT () 2020 Erktan, Pollierer and Scheu. This is an open-access article distributed under the terms of the Creative Commons Attribution License (CC BY). The use, distribution or reproduction in other forums is permitted, provided the original author(s) and the copyright owner(s) are credited and that the original publication in this journal is cited, in accordance with accepted academic practice. No use, distribution or reproduction is permitted which does not comply with these terms.

\section{YOUNG REVIEWERS}

\section{CECÍLIA, AGE: 9}

Cecilia is a bright young lady that loves to play chess and is very curious about all kind of random things. She just wants to know how everything works and likes to later show off all the facts that her brain collected.

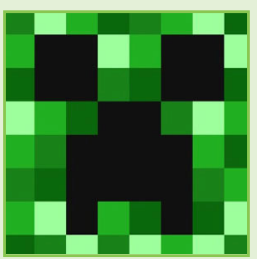

NYNKE, AGE: 12

$\mathrm{Hi}$, my name is Nynke.

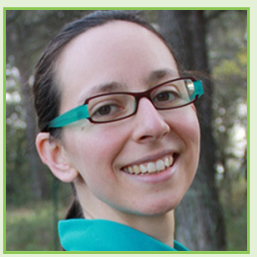

\section{AUTHORS}

\section{AMANDINE ERKTAN}

I am a post-doc at the University of Göttingen in Germany. I am interested in understanding how living organisms shape the soil structure, and vice-versa. I first worked on plant roots and studied how they structure the soil. I quickly realized that roots are not the only engineers of the soil. There are countless microbes and animals in the soil and their roles are crucial to determining the soil structure. I am now acquiring new skills studying soil animals and hope to shed light on how plant roots, microbes and soil animals interact in the soil matrix. *aerktan@gwdg.de 


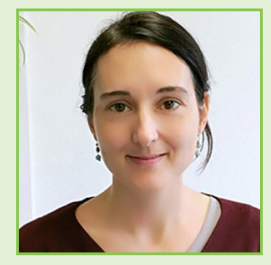

\section{MELANIE M. POLLIERER}

I am a post-doc at the University of Göttingen, Germany. My main interest concerns soil animal food webs. Since it is hard to observe what soil animals really eat, I use indirect methods to find out more. In my Ph.D. thesis, I analyzed fatty acids in soil animals and followed the fate of labeled carbon from plants to animals. Now, I use another new method: I analyze stable forms of carbon and nitrogen in amino acids, allowing even more detailed insights into the diet of consumers.

\section{STEFAN SCHEU}

While studying biology in Tübingen and Göttingen between 1979 and 1986, I was fascinated by the enormous diversity and important role of soil invertebrates. Ever since, I have investigated the structure and functioning of soil animal communities, first during my Ph.D. at the University of Göttingen and later as a post-doc in Calgary and Göttingen. In 1997, I established my own research group as Professor of Zoology and Ecology at Darmstadt University of Technology, and in 2008 back at the University of Göttingen as Chair of Animal Ecology. Here, we investigate the structure, function, and evolution of soil animal species and communities. 